\title{
Evidence-based position paper on Physical and Rehabilitation Medicine (PRM) professional practice for people with obesity and related comorbidities. The European PRM position (UEMS PRM Section)
}

\author{
Paolo CAPODAGLIO ${ }^{1 *}$, Elena ILIEVA ${ }^{2}$, Aydan ORAL ${ }^{3}$, Carlotte KIEKENS ${ }^{4}$, Stefano NEGRINI 5, 6 , \\ Enrique VARELA DONOSO ${ }^{7}$, Nicolas CHRISTODOULOU ${ }^{8}$, UEMS-PRM EBPP Methodological Group $\$$
}

\begin{abstract}
${ }^{1}$ Department of Physical and Rehabilitation Medicine, Istituto Auxologico Italiano, Piancavallo, Verbania, Italy; ${ }^{2}$ Department of Physical and Rehabilitation Medicine, Medical Faculty, Medical University of Plovdiv, Plovdiv Bulgaria; ${ }^{3}$ Department of Physical Medicine and Rehabilitation, Istanbul Faculty of Medicine, Istanbul University, Istanbul, Turkey; ${ }^{4}$ Department of Physical and Rehabilitation Medicine, University Hospital Leuven, Leuven, Belgium; 5Department of Physical and Rehabilitation Medicine, University of Brescia, Brescia, Italy; ${ }^{2}$ RCCS Fondazione Don Gnocchi ONLUS, Milan, Italy; ${ }^{7}$ Department of Physical Medicine and Rehabilitation, Medicine Faculty, University Complutense, Madrid, Spain; ${ }^{8}$ Physical Medicine and Rehabilitation, Medical School, European University Cyprus, Cyprus
\end{abstract}

*Corresponding author: Paolo Capodaglio, Orthopedic Rehabilitation Unit and Clinical Lab for Gait Analysis and Posture Ospedale, San Giuseppe Istituto Auxologico Italiano IRCCS, Piancavallo, Verbania, Italy. E-mail: p.capodaglio@auxologico.it

$\$$ Members are listed at the end of the paper.

\section{A B S T R A C T}

INTRODUCTION: The WHO world health statistics report in 2015 shows that in Europe the overall obesity rate among adults is $21.5 \%$ in males and $24.5 \%$ in females. Obesity has important consequences for morbidity, disability and quality of life. The aim of the paper was to improve physical and rehabilitation medicine physicians' professional practice for the rehabilitation of patients with obesity and related comorbidities. EVIDENCE ACQUISITION: A systematic review of the literature and a Consensus procedure by means of a Delphi method process has been performed involving the delegates of all European countries represented in the UEMS PRM Section.

EVIDENCE SYNTHESIS: The systematic literature review is reported together with the 13 recommendations from the Delphi procedure. CONCLUSIONS: The professional role of PRM physicians in obesity is to propose a complete PRM treatment for the patients considering the comorbidities, impairments, activity limitations and participation restrictions, providing medical care and leadership to the multidisciplinary team, coordinating the individual PRM project developed in team in agreement with the patient and his family/care givers.

(Cite this article as: Capodaglio P, Ilieva E, Oral A, Kiekens C, Negrini S, Varela Donoso E, et al.; UEMS-PRM EBPP Methodological Group. Evidence-based position paper on Physical and Rehabilitation Medicine (PRM) professional practice for people with obesity and related comorbidities. The European PRM position (UEMS PRM Section). Eur J Phys Rehabil Med 2017;53:611-24. DOI: 10.23736/S1973-9087.17.04880-8)

Key words: Obesity - Disability evaluation - Rehabilitation.

\section{Introduction}

$\mathrm{O}$ besity is a metabolic disease (ICD-10 code E66) that has reached epidemic proportions. The World Health Organization (WHO) has declared obesity as the largest global chronic health problem in adults. Obesity is a gateway to ill health, and it has become one of the leading causes of disability and death, affecting not only adults but also children and adolescents worldwide. ${ }^{1-3}$ The WHO world health statistics report in 2015 


\section{COPYRIGHT $^{(} 2017$ EDIZIONI MINERVA MEDICA}

shows that in the European region the overall obesity rate among adults is $21.5 \%$ in males and $24.5 \%$ in females. ${ }^{4} \mathrm{An}$ increase to $36.9 \%$ and to $38.0 \%$ in 2013 in the proportion of men and women, respectively, whose body mass index (BMI) was greater than 25 were noted in the Global Burden of Disease Study. ${ }^{5}$ Obesity has important consequences for morbidity, disability and health-related quality of life. Obesity entails a higher risk of developing type 2 diabetes, cardiovascular diseases, obstructive sleep apnea syndrome and obesity hypoventilation syndrome, several common forms of cancer, osteoarthritis and other health problems including musculoskeletal pain. ${ }^{6-10}$ Prevention of obesity is prospectively very important, but the challenge is rather the progression of the disabilities already present posing a significant challenge for Physical and Rehabilitation Medicine (PRM) specialists. The health and economic burden resulting from obesity and its consequences is not only based on mortality and the financial costs of hospital admissions and treatment of comorbidities, but also on significant ensuing disability with limitations in functioning which are well documented in the International Classification of Functioning (ICF) Core Sets for Obesity. ${ }^{11}$ Disability burden attributable to obesity is substantial, high BMI accounting for $3.8 \%$ of worldwide disability adjusted life years in $2010{ }^{12}$ with 134 million years in 2013 as the leading risk factor almost in all world regions. ${ }^{13}$

Today there is no uniformity among different countries across Europe and in the world in the PRM approach. The existing documents in Europe are clinical guidelines for the treatment and management of obesity in the hospital and in the long term. Physiotherapy interventions are usually not explicitly and specifically included in the existing clinical guide lines about the treatment of obese patients. The availability of evidence of effectiveness of interventions refers only to combined interventions (diet, physical activity, behavioural therapy, pharmacological therapy, bariatric surgery) and not to specific PRM interventions. For these reasons the European Union of Medical Specialists (UEMS) - PRM Section decided to develop one of its evidence based position papers (EBPPs) on obesity and related comorbidities, representing the official position of the European Union. The aim of the paper is to improve PRM specialists' professional practice for patients with obesity and related comorbidities.

\section{Evidence acquisition}

\section{Literature search}

This paper has been developed according to the Methodology defined by the Professional Practice Committee of the UEMS-PRM Section. ${ }^{7}$ The systematic review of the literature has been performed in PubMed the $6^{\text {th }}$ of February, 2016. A library scientist conducted an extensive a priori literature search for articles related to obesity and rehabilitation.

The search included articles extracted from the following databases: MEDLINE, EMBASE (Current Contents), SPORTDiscus, SUM, Scopus, CINAHL, AMED, BIOMED, PubMed, ERIC, the Cochrane Controlled Trials, and PEDro. A hand search of the reference lists of potential case-control studies (CCSs) also was performed. The 4 strings used for the first selection are reported in Appendix I. Two reviewers (CP and BA, in the Acknowledgments) performed the selection at each stage. The subsequent Consensus with Delphi procedure has followed the 4 steps proposed by the Methodology paper. ${ }^{14}$

\section{Evidence synthsis}

The criterion for including the studies has been the professional relevance for PRM physicians as judged by the author CP and by BA cited in the Acknowledgements, with the author resolving conflicts. The Strengh of Evidence (SoE) and the Strength of Recommendation (SoR) are given according to the Methodology paper.

The PubMed search (string 1 to 3 ) evidenced the following papers: a total of 462 papers ( 231 from string 1 , 110 from string 2, 121 from string 3), from which we excluded 319 titles not relevant to PRM, and considered 143 titles for abstract review (69 from string 1, 42 from string 2, 32 from string 3) (Figure 1).

The Cochrane search (string 4) provided 2 systematic reviews and 110 RCTs (10-year time), from which we selected 32 titles and 8 abstracts. The latter overlapped with the abstracts found in the PubMed search.

We then excluded 82 abstracts not relevant to PRM and included for paper review 61 papers.

Twenty-one papers (10 from string 1 and 11 from string 3 ) out of the 61 plus 8 additional papers (5 European clinical guidelines, 1 American clinical guideline and 3 expert papers) were considered to produce this EBPP (Appendix II). 


\section{COPYRIGHT $^{(} 2017$ EDIZIONI MINERVA MEDICA}

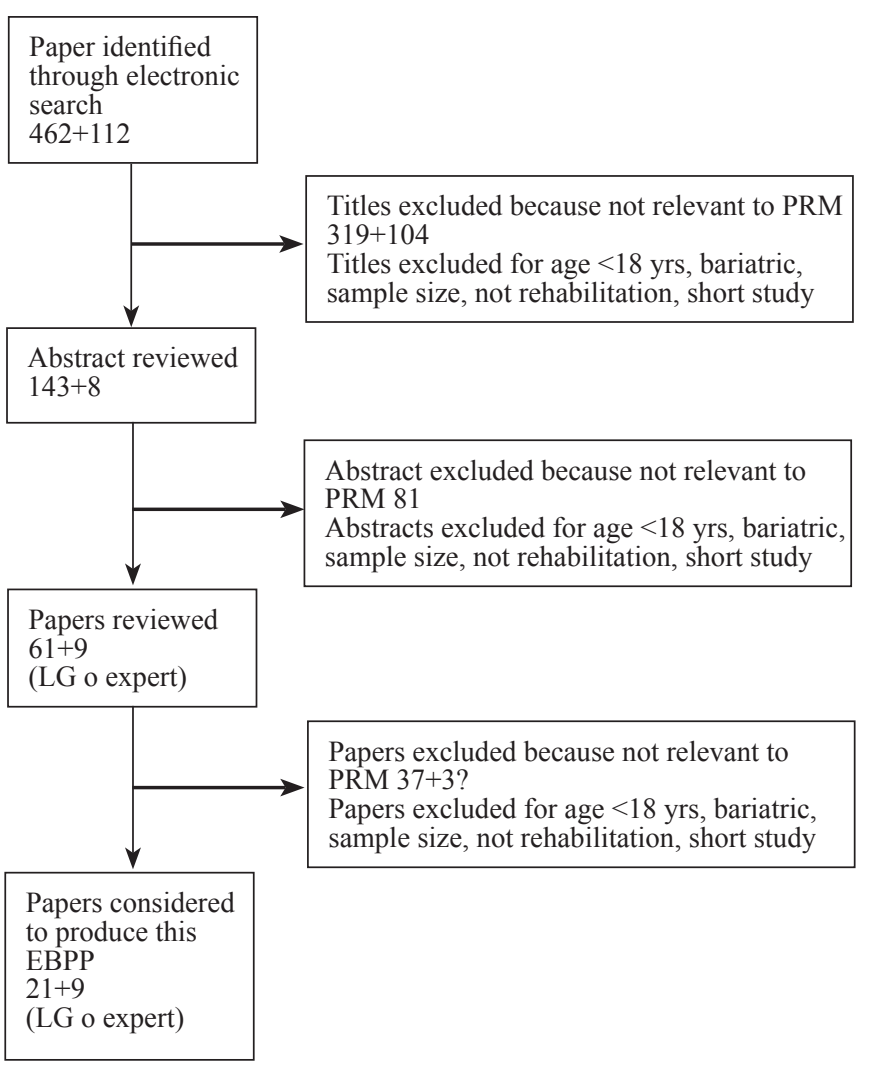

Figure 1.-Flow chart of papers selection.

The 6 existing clinical guidelines are intended for the treatment and management of obesity in the hospital and in the long term but are not to serve as a standard of care. They are of particular interest to those working in primary care, secondary and tertiary weight management services and those involved in management of services for long term conditions especially diabetes and cardiovascular disease. The 3 key treatments considered in the guidelines (we have excluded bariatric surgery and pharmacological interventions) are: nutrition, physical exercise and behavioral therapy (Table I).

These treatments are complementary and have to be offered to the patient at the same time. The combination of these 3 treatments has been proved to be more effective than single treatment.

The only 2 papers specifically referring to physiotherapy interventions are the Italian Guidelines and the Ottawa Clinical Practice Guidelines (Appendix II).

The Italian document provides the following recommendations:
- "the rehabilitation pathway of the obese patient should be characterized by the integration of nutritional, physical/functional rehabilitation (physiotherapy, therapeutic exercise, physical reconditioning, adapted physical activity), psycho-educational (therapeutic education and short focused psychotherapeutic interventions), rehabilitative nursing interventions" (Level: IV; Strength of Recommendation: A).

— "The intensity of the rehabilitative intervention should depend on the level of severity and comorbidities, frailty of the psychic status, degree of disability and quality of life of the patient" (Level: VI; Strength of Recommendation: A).

The Ottawa Panel found evidence to support the use of diet or physical activity/physiotherapy programs for the overall management of osteoarthritis of the knee in obese patients. Results of positive recommendations (grades A and C) from included studies with high methodological quality (Jadad scale score 3 ) indicate that diet or physical activity programs were promising for:

- short-term (6-month) pain relief (2 grade A recommendations, 6 grade $\mathrm{C}$ recommendations);

- long-term follow-up (18-month) pain relief (3 grade $\mathrm{C}$ recommendations);

- improvement of torque ( 2 grade $\mathrm{C}$ recommendations);

- functional status (2 grade A recommendations, 2 grade $\mathrm{C}$ recommendations);

- self-efficacy (2 grade A recommendations, 2 grade $\mathrm{C}$ recommendations);

- endurance ( 2 grade A recommendations);

- mobility (1 grade A recommendation, 3 grade $\mathrm{C}$ recommendations);

- psychological well-being (2 grade A recommendations, 1 grade $\mathrm{C}$ recommendation).

The Ottawa Panel recommends reducing weight prior to the implementation of weight-bearing exercise to maintain joint integrity and to avoid joint disease and dysfunction and the inclusion of diet or physical activity programs in the management of ostheoarthritis among individuals who are obese.

\section{Consensus}

\section{OVERALL GENERAL RECOMMENDATION}

The professional role of PRM physicians in rehabilitation of persons with obesity and related condi- 


\section{COPYRIGHT ${ }^{\odot} 2017$ EDIZIONI MINERVA MEDICA}

TABLE I.-Summary of the recommended 3 key-treatments in the existing European Guidelines.

\begin{tabular}{ll}
\hline & \multicolumn{1}{c}{ Nutrition } \\
\hline NICE & 600 kcal/day deficit low-fat diets, in \\
combination with expert support and & intensive \\
& follow-up. Low-calorie diets (800-1600 \\
& kcal/day) are less \\
& likely to be nutritionally complete. Only \\
& consider very-low-calorie diets, as part \\
& of multi-component program for rapidly \\
& losing weight (for example, people who \\
& need joint replacement surgery or who are \\
& seeking fertility services)
\end{tabular}

Scottish

(2010)

$600 \mathrm{kcal} /$ day energy deficit, individually tailored

German Reduction fat intake only: daily energy (2007) deficit about $500 \mathrm{kcal}$. The fat intake is reduced to about 60 grams per day and the consumption of carbohydrates not limited. Average weight loss of 3.2 $-4.3 \mathrm{~kg}$ over 6 months. For moderately energy-reduced varied diet, energy deficit $500-800 \mathrm{kcal} /$ day. Carbohydrates and protein are also reduced. Average of 5.1 $\mathrm{kg}$ over12 months can be successfully lost

Italian

(2010)

Depending on energy consumption, $500 \mathrm{e}$ $1000 \mathrm{kcal}$ caloric restriction.

European Balanced hypocaloric diets result in (2015) clinically meaningful weight loss. An emphasis on the macronutrient proportion (low fat, low carbohydrate or high protein etc.) has not proved better than a balanced hypocaloric diet, except for low-glycaemic load diets. Beneficial effects on reducing risk factors for cardiovascular disease and type 2 diabetes as well as on promoting adherence. A $15-30 \%$ decrease in energy
Self-monitoring of behavior and progress stimulus control goal setting slowing rate of eating ensuring social support. Encourage to increase physical activity even if they do not lose weight because of the other health benefits, reduce amount of time spent inactive

A combination of active support for diet plus behavioral therapy (problem solving, relapse prevention, stimulus control, dealing with problem situations, assertion, and behavior chain analysis) is effective for weight loss at 12 months.

Self monitoring stimulus control cognitive restructuring (modifying unhelpful thoughts/thinking patterns) goal setting problem solving assertiveness training slowing the rate of eating reinforcement of changes relapse prevention

bolster motivation to comply with the nutrition and exercise recommendations, for long-term weight reduction or stabilization. Self-observation of eating, drinking and exercise habits.

Gradual introduction of flexible, controlled eating habits.

Learning stimulus control techniques to decrease eating impulses.

Use of positive reinforcement in order to strengthen new eating habits and prevent relapse.

Social support relapse prophylaxis and management

Behavioral therapy + life style changes more effective than life style changes only. Techniques: therapeutic alliance and adherence, motivation, problem solving, empowerment, narrative medicine.

Reduce sedentary behavior and increase daily activities. Patients should be advised and helped in undertaking (or increasing) physical activity. Exercise advice must be tailored to the patient's ability and health and focus on a gradual increase to levels that are safe.

Cognitive-behavioral therapy includes self-monitoring, techniques controlling the process of eating, stimulus control
Physical exercise

At least 30 min moderate intensity physical activity 5 days/week. 1 session or several sessions lasting $10 \mathrm{~min}$ or more.

To prevent obesity, 45-60 minutes moderate-intensity activity/day. People who have been obese and have lost weight may need 60-90 min activity/day to avoid regaining weight. Activities that can be incorporated into everyday life. Consider person's current physical fitness

Physical activity approximately 1,800 $2,500 \mathrm{kcal} /$ week $(225-300 \mathrm{~min} /$ week at moderate intensity)

5 hours additional physical activity per week (additional energy consumption of $2500 \mathrm{kcal} /$ week). To stabilize weight, 3-5 h/ week of increased activity (at least $1500 \mathrm{kcal}$ ).

Training intensity at $75 \%$ of the maximum heart rate if no contraindications. Combination of endurance with muscle building training.

150-250 min a week induce modest loss (2.3 kg in 6-12 months), $250-400 \mathrm{~min}$ a week a $5.0-7.5 \mathrm{~kg}$ reduction in 6-12 months.

To prevent regain 200 min a week of moderate intensity physical activity.

Additive benefits of combining exercise with caloric restriction on reducing body weight and body fat and preservation of FFM as compared to diet alone. Aerobic training is the optimal mode of exercise for reducing fat mass and body mass while a programme including resistance training is least $150 \mathrm{~min} /$ week of moderate aerobic training is the optimal mode of exercise for reducing fat mass and body mass while a 


\section{COPYRIGHT ${ }^{\odot} 2017$ EDIZIONI MINERVA MEDICA}

EVIDENCE BASED POSITION PAPER ON PRM PROFESSIONAL PRACTICE

CAPODAGLIO

TABLE I.-Summary of the recommended 3 key-treatments in the existing European Guidelines (continues).

\begin{tabular}{|c|c|c|}
\hline Nutrition & Behavioral & Physical exercise \\
\hline $\begin{array}{l}\text { (calorie) intake from habitual intake } \\
\text { appropriate. Recommended energy deficit } \\
\text { of } 600 \mathrm{kcal} / \mathrm{day} \text { will predict a weight } \\
\text { loss of about } 0.5 \mathrm{~kg} \text { weekly. Low-calorie } \\
\text { diets have an energy content between } \\
800 \text { and } 1200 \mathrm{kcal} / \mathrm{day} \text {. VLCDs usually } \\
\text { provide less than } 800 \mathrm{kcal} / \mathrm{day} \text { and may } \\
\text { be used only as part of a comprehensive } \\
\text { programme under supervision. Unsuitable } \\
\text { as a sole source of nutrition for children } \\
\text { and adolescents, pregnant or lactating } \\
\text { women and the elderly. Meal replacement } \\
\text { diets (substitution of one or two daily meal } \\
\text { portions by VLCD) may contribute to } \\
\text { nutritionally well-balanced diet and weight } \\
\text { loss maintenance. }\end{array}$ & $\begin{array}{l}\text { and re-enforcement as well as cognitive } \\
\text { and relaxation techniques. CBT can } \\
\text { be provided not only by registered } \\
\text { psychologists but also by other trained } \\
\text { health professionals such as physicians, } \\
\text { dieticians, exercise physiologists } \\
\text { or psychiatrists. Physicians should } \\
\text { recognize where psychological or } \\
\text { psychiatric issues interfere with successful } \\
\text { obesity management, e.g. depression. } \\
\text { Psychological support and/or treatment } \\
\text { will then form an integral part of } \\
\text { management; in special cases (anxiety, } \\
\text { depression and stress), referral to a } \\
\text { specialist may be indicated. }\end{array}$ & $\begin{array}{l}\text { program including resistance training } \\
\text { is needed for increasing lean mass At } \\
\text { least } 150 \mathrm{~min} / \text { week of moderate aerobic } \\
\text { exercise with three weekly sessions of } \\
\text { resistance exercise. }\end{array}$ \\
\hline
\end{tabular}

tions includes provision of rehabilitation diagnosis and treatment emphasizing function and quality of life, medical care of the existing comorbidities, prescription of bariatric aids for independence, leadership to the multidisciplinary rehabilitation team bringing a distinctive holistic perspective to the patient care process, developing rehabilitation protocols in different settings in relation to the phases of instability of the condition and taking charge of the return-to-home (avoidance of environmental barriers, prescription of mobility/transferring aids) and returnto-work phases.

\section{Recommendations on PRM Physicians' role in Medi- CAL Diagnosis ACCORDING TO ICD}

It is recommended that PRM physicians dealing with obesity and comorbidities gain specific and wide expertise in the specific medical diagnoses and treatment approaches of these patients. They should work in team with other specialties to develop the required PRM treatments. It is also important for PRM physicians to consider obesity risk in people with long-term disabilities already in rehabilitation.

\section{RECOMMENDATIONS ON PRM PHYSICIANS' ROLE IN PRM DIAGNOSIS ACCORDING TO ICF}

In the diagnostic phase, an assessment of motor function (muscular strength, balance, endurance) and car- diorespiratory capacity, disability, health-related quality of life, musculoskeletal pain and other chronic pain conditions and limitations should be performed (Level: III; Strength of Recommendation: A).

\section{RECOMMENDATIONS ON PRM PHYSICIANS' ROLE IN PRM ASSESSMENT ACCORDING TO ICF}

The rehabilitation plan should be developed according to the ICF model. PRM treatment should be regularly assessed through a complete PRM assessment including evaluation of disease, comorbidity and impairment but also activity limitations and participation restrictions due to health condition and/or treatments, taking into account contextual factors, including environmental and personal factors.

\section{RECOMMENDATIONS ON PRM MANAGEMENT AND PROCESS}

Inclusion criteria (e.g. when and why to prescribe PRM interventions).-PRM interventions should be proposed when functional capacity and quality of life are reduced due to excessive body mass and presence of disabling comorbidities. Specific PRM interventions are to be prescribed aimed at minimizing joint loads, improve muscle strength, balance, endurance and conditioning, maximizing motor, cardiorespiratory function and independence also with prescription of assistive technologies and ergonomic solutions. Admission to inpatient programs should be granted even in the 


\section{COPYRIGHT $^{\odot} 2017$ EDIZIONI MINERVA MEDICA}

absence of an acute event, based on severity of disability and clinical appropriateness. (Level: III; Strength of Recommendation: A).

\section{RECOMMENDATIONS ON PROJECT DEFINITION (DEFINITION OF THE OVERALL AIMS AND STRATEGY OF PRM INTER- VENTIONS)}

It is recommended that the PRM programme is proposed in centers where all the team (PRM physician, physiotherapist, occupational therapist, trainer, dietician, psychologist, endocrinologist and other specialties) is present. The integrated individual rehabilitation programme encompasses different areas of intervention and short- and long-term goals:

1) Nutritional intervention finalized to: restore correct eating habits (quality, quantity) in the long term; achieve a weight loss of at least $5 \%$ of the initial body weight in the short term and $10 \%$ in the long term with significant reduction of the fat mass and maintenance/ increase of the lean mass.

2) Motor/functional rehabilitation programme (see "PRM interventions").

3) Therapeutic education and psychotherapeutic interventions targeted to: acknowledge the real needs of the patients; correct the false beliefs on nutrition and physical activity; train self-control and management in eating, physical activity, stress and anxiety (self-monitoring of eating, physical activity and weight, stimulus control, problem solving, cognitive restructuration); improve illness behavior.

4) Rehabilitative nursing, interventions performed by occupational therapists, physiotherapists and nurses and targeted to: improve patients' responses to chronic conditions, disability and pathological life styles; increase the social and environmental supports and compensations; protect and stimulate the functional and relational capacities in order to optimize participation to rehabilitation activities and health care programs (Level: IV; Strength of Recommendation: A).

\section{RECOMMENDATIONS ON TEAM WORK (PROFESSIONALS IN- VOLVED AND SPECIFIC MODALITIES OF TEAM WORK)}

An interdisciplinary team is mandatory for effective implementation of rehabilitation for obesity-related disability. The integration of several medical specialties, including clinical nutrition, endocrinology, psychiatry, physical and rehabilitation medicine, cardiology, pneumology and different health professions, including dietitians, psychologists, physiotherapists, occupational therapists and nurses is required. The PRM physician brings a distinctive holistic perspective to the patient care process, with a particular focus on all dimensions of functioning involving body structures and functions, activities and participation, and contextual factors, whereas members of other disciplines treat particular ICF body structures and functions. The patient and his family are part of the team. For possible surgical options, a bariatric surgeon must be part of the team as well.

\section{RECOMMENDATIONS ON PRM INTERVENTIONS}

It is recommended that PRM interventions include physical reconditioning with adapted physical activity, motor rehabilitation finalized at improving hypotonic and hypotrophic muscles due to disuse; restore range of motion; improve cardio-circulatory and respiratory capacities; physical modalities or other procedures for pain reduction

\section{RECOMMENDATIONS ON OUTCOME CRITERIA}

It is recommended that the following outcome criteria are used: 1) nutritional outcomes (reduce BMI, body weight, LDL cholesterol, improve body composition); 2) motor/functional outcomes (reduce pain, improve physical capacities, function, activities of daily living and tolerance to effort); 3) behavioral and psychological outcomes (improve quality of life, correct nutritional and physical behavior etc.).

\section{RECOMMENDATIONS ON LENGTH/DURATION/INTENSITY OF TREATMENT (OVERALL PRACTICAL PRM APPROACH)}

It is recommended that the intensity and duration of the interventions depend on the level of severity and comorbidities, frailty of the psychological status, degree of disability and quality of life of the patient (Level: IV; Strength of Recommendation: A).

Inpatient or specialised extra hospital rehabilitation facilities (up to 1-month stay) admit patients with disabilities susceptible of modifications which require specialized medical rehabilitative and therapeutic care in 


\section{COPYRIGHT $^{(} 2017$ EDIZIONI MINERVA MEDICA}

terms of complexity and/or duration of rehabilitative interventions provided by the health care professionals and the rehabilitation team.

Outpatient rehabilitation is characterized by a moderate need for clinical therapeutic care and by high demands of supportive interventions for the patients undergoing treatment.

\section{RECOMMENDATIONS ON DISCHARGE CRITERIA (E.G. WHEN AND WHY TO END PRM INTERVENTIONS)}

It is recommended that patients stay in rehabilitation until reduction of disability (scales, questionnaires etc.), improvement in functional capacity (scales, functional tests), clinical steady state and reduction of clinical risk factors are reached. Rehabilitation transition settings, including community settings, should be considered after discharge for the delivery of PRM interventions for favourable long-term outcomes.

\section{RECOMMENDATIONS ON FOLLOW-UP}

A multidisciplinary (dietician, PRM specialist, endocrinologist, psychologist) follow-up at regular intervals based on the individual's specific situation and eventually a prescription of outpatient PRM interventions in different settings are recommended in the long-term phase.

\section{RECOMMENDATIONS ON FUTURE RESEARCH ON PRM PRO- FESSIONAL PRACTICE}

The leading role of the PRM specialists in this field should translate into providing new evidences of the effectiveness of specific PRM interventions on functioning and quality of life of obese patients with comorbid conditions. ICF compatible evaluation instruments should be implemented. Evidence-based methods to generate the patient's own activity and self-responsibility (web-based feedback and training) should also be implemented. ${ }^{15-17}$

\section{Discussion}

The environment where the inpatient rehabilitation programmes are held should be structurally and ergonomically adequate and safe for both patients and staff alike, with the adequate presence of bariatric aids and lifting/transferring devices according to the number of obese inpatients.

Not being specifically related to an acute event, the intensity of the interventions should depend on the level of severity and comorbidities, frailty of the psychological status, degree of disability and quality of life of the patient. Using the ICF, it appears that the most impaired functions are included in chapter b2 - sensory functions and pain, and chapter b7 - neuromusculoskeletal and movement-related functions; the most impaired structures are related to chapter s8 - skin and related structures. The most limited activities are included in chapters $\mathrm{d} 2$ - general tasks and demands and $\mathrm{d} 4$ - mobility. The most extended facilitators are within chapter e 1 - products and technology; chapter e2 - natural environment and human-made changes to environment, describes the barriers. ${ }^{18}$

A multidimensional approach able to provide front line assessment and preventive strategies, risk stratification, and disease management is needed. For that purpose a team approach and the integration of several medical specialties, including clinical nutrition, endocrinology, psychiatry, psychology, rehabilitation medicine, and different health professions, including dietitians, psychologists, physiotherapists, occupational therapists and nurses is required. It is therefore mandatory to assess quality of life, disability, motor function (muscle strength, balance, tolerance to effort) and musculoskeletal problems (articular pain, limitations of the range of motion). Multidimensional rehabilitation can also be applied to complicated bariatric surgery patients in both the preoperative and postoperative period. Patients with chronic pain who may not have been alleviated after surgery may benefit from PRM interventions with special considerations for this specific group of individuals. ${ }^{10}$

There is a need for multiple settings in relation to the phases of instability of the condition. ${ }^{19,20}$ The model of organisation for long-term PRM depends on the existing traditions of the country.

Intensive (inpatient or specialised extra hospital facilities) rehabilitation interventions are directed to the recovery of major disabilities susceptible of modifications which require specialized medical rehabilitative and therapeutic care in terms of complexity. 


\section{COPYRIGHT $^{(} 2017$ EDIZIONI MINERVA MEDICA}

Outpatient rehabilitation is characterized by a moderate need for clinical therapeutic care and by high demands of supportive interventions for the patients undergoing treatment. PRM physicians should also take into account that higher rates of obesity are observed in persons with disabilities as reported in the World Report on Disability. ${ }^{21}$ Overweight and obesity prevention programs may also be adapted to persons living with a disability such as spinal cord injury. 22 A systematic review pointed to the effectiveness of physical activity/exercise including strength training with a duration exceeding 15 minutes in the short-term in children with disabilities. ${ }^{23}$

\section{Conclusions}

The PRM physician is responsible for the functional and social assessment of persons with obesity with related comorbidities and for setting up a comprehensive strategy - a PRM problem-oriented program of care. It should include education of the patients, exercise, physical modalities, occupational therapy, aids and orthoses, pharmacological interventions and proper advice to refer to surgical interventions when the conservative approach is ineffective.

PRM physicians, guided by the ICF, are in a position to be helpful to these patients largely. Although there are a number of effective PRM interventions based on scientific evidence for the treatment of patients with obesity with related comorbidities there seems to be a need for more high-quality trials in this field. Especially studies on activities and participation and environmental factors (i.e. work) components of the ICF are required to enable PRM physicians to make evidencebased decisions on treatments to ensure the best care of their patients.

The specialty of PRM is well qualified to address the problems of chronicity and obesity in particular. ${ }^{24}$ For many PRM physicians, however, the prescription of exercise for obese individuals will be venturing into a different realm of practice, beyond their ordinary experience. Some may feel the need to reinforce and further develop their skills in specific areas of exercise and nutrition application for these populations. PRM in general will benefit from widespread education and research efforts in this area.

\section{References}

1. World Health Organization. Obesity and overweight. Fact sheet No311. Updated March 2011 [Internet]. Available from: http://www. who.int/mediacentre/factsheets/fs311/en/index.html [cited 2011, Nov $15]$.

2. Withrow D, Alter DA. The economic burden of obesity worldwide: a systematic review of the direct costs of obesity. Obes Rev 2010;12:131-41.

3. Yanovski SZ, Yanovski JA. Obesity prevalence in the United States -Up, Down or sideway. New Engl J Med 2011;364:987-9.

4. WHO | World report on disability [Internet]. WHO. Available from: http://www.who.int/disabilities/world_report/2011/en/ [cited 2014, Nov 8].

5. Ng M, Fleming T, Robinson M, Thomson B, Graetz N, Margono C, et al. Global, regional, and national prevalence of overweight and obesity in children and adults during 1980-2013: a systematic analysis for the Global Burden of Disease Study 2013. Lancet 2014;384:76681. Erratum in: Lancet 2014;384:746.

6. Backholer K, Wong E, Freak-Poli R, Walls HL, Peeters A. Increasing body weight and risk of limitations in activities of daily living: a systematic review and meta-analysis. Obesity Reviews 2012;13:456-68

7. Capodaglio P, Brunani A, Giustini A, Negrini S, Saraceni LM, Akyüz $\mathrm{G}$, et al. Disability in obesity with comorbidities. A perspective from the PRM Societies. Eur J Phys Rehabil Med 2014;50:129-32.

8. Smith SM, Sumar B, Dixon KA. Musculoskeletal pain in overweight and obese children. Int J Obes (Lond) 2014;38:11-5.

9. Verrotti A, Di Fonzo A, Penta L, Agostinelli S, Parisi P. Obesity and headache/migraine: the importance of weight reduction through lifestyle modifications. Biomed Res Int 2014;2014:420858

10. Narouze S, Souzdalnitski D. Obesity and chronic pain: systematic review of prevalence and implications for pain practice. Reg Anesth Pain Med 2015;40:91-111.

11. Stucki A, Daansen P, Fuessl M, Cieza A, Huber E, Atkinson R, et al. ICF Core Sets for obesity. J Rehabil Med 2004;(44 Suppl.):107-13.

12. Lim SS, Vos T, Flaxman AD, Danaei G, Shibuya K, Adair-Rohani H, et al. A comparative risk assessment of burden of disease and injury attributable to 67 risk factors and risk factor clusters in 21 regions, 1990-2010: a systematic analysis for the Global Burden of Disease Study 2010. Lancet 2012;380:2224-60.

13. GBD 2013 Risk Factors Collaborators, Forouzanfar MH, Alexander L, Anderson HR, Bachman VF, Biryukov S, et al. Global, regional, and national comparative risk assessment of 79 behavioural, environmental and occupational, and metabolic risks or clusters of risks in 188 countries, 1990-2013: a systematic analysis for the Global Burden of Disease Study 2013. Lancet 2015;386:2287-323.

14. Negrini S, Kiekens C, Zampolini M, Wever D, Varela Donoso E, Christodoulou N. Methodology of "Physical and Rehabilitation Medicine practice, Evidence Based Position Papers: the European position" produced by the UEMS-PRM Section. Eur J Phys Rehabil Med 2016;52:134-41.

15. WHO. International Classification of Functioning, Disability and Health. Geneva: World Health Organization; 2001.

16. Robinson KT, Butler J. Understanding the causal factors of obesity using the International Classification of Functioning, Disability and Health. Disabil Rehabil 2011;33:643-51.

17. Capodaglio P, Lafortuna C, Petroni ML, Salvadori A, Gondoni L, Castelnuovo $\mathrm{G}$, et al. Rationale for hospital-based rehabilitation in obesity with comorbidities. Eur J Phys Rehabil Med 2013;49:399417.

18. Brunani A, Raggi A, Sirtori A, Berselli ME, Villa V, Ceriani F, et al. ICF-OBESITY Group. An ICF-Based Model for Implementing and Standardizing Multidisciplinary Obesity Rehabilitation Programs within the Healthcare System. Int J Environ Res Public Health 2015;12:6084-91.

19. Donini LM, Cuzzolaro M, Spera G, Badiali M, Basso N, Bollea MR, et al. Obesity and Eating Disorders. Indications for the different lev- 


\section{COPYRIGHT ${ }^{\odot} 2017$ EDIZIONI MINERVA MEDICA}

els of care. An Italian Expert Consensus Document. Eat Weight Disord 2010;15(1-2 Suppl.):1-31.

20. Donini LM, Cuzzolaro M, Gnessi L, Lubrano C, Migliaccio S, Aversa A, et al. Obesity treatment: results after 4 years of a Nutritional and Psycho Physical Rehabilitation Program in an outpatient setting. Eat Weight Disord 2014;19:249-60.

21. World Health Organization, World Bank. World Report on Disability. Geneva, WHO, 2011 [Internet]. Available from: http://www.who.int/ disabilities/world report/2011/en/ [cited 2016, Jul 18].
22. Nash MS, Kressler J. Model Programs to Address Obesity and Cardiometabolic Disease: Interventions for Suboptimal Nutrition and Sedentary Lifestyles. Arch Phys Med Rehabil 2016;97(9 Suppl.):S238-46.

23. McPherson AC, Keith R, Swift JA. Obesity prevention for children with physical disabilities: a scoping review of physical activity and nutrition interventions. Disabil Rehabil 2014;36:1573-87.

24. Laskoski ER. Action on Obesity and Fitness: The Physiatrist's Role. PM\&R 2009;1:795-7.

Group name.-The UEMS-PRM EBPP Methodological Group includes: Nicolas CHRISTODOULOU, Medical School, Physical Medicine and Rehabilitation, European University Cyprus, Cyprus; Carlotte KIEKENS, University Hospitals Leuven, Belgium; Stefano NEGRINI, Department of Clinical and Experimental Sciences, University of Brescia - IRCCS Fondazione Don Gnocchi, Milan, Italy; Enrique VARELA DONOSO, Department of Physical Medicine and Rehabilitation, Medicine Faculty, University Complutense, Madrid, Spain

Conflicts of interest.-The authors certify that there is no conflict of interest with any financial organization regarding the material discussed in the manuscript. Acknowledgements.-The authors are indebted to Amelia Brunani from the Istituto Auxologico Italiano for her professional help in paper selection at each stage.

Article first published online: July 5, 2017. - Manuscript accepted: July 4, 2017. - Manuscript received: June 22, 2017. 


\section{COPYRIGHT ${ }^{(} 2017$ EDIZIONI MINERVA MEDICA}

\section{APPENDIX}

APPENDIX I.-The 4 strings used for first selection.

String 1) (obesit[All Fields] OR obesit'a[All Fields] OR obesit'asban[All Fields] OR obesita[All Fields] OR obesita'[All Fields] OR obesita'e[All Fields] OR obesitaksen[All Fields] OR obesitaksessa[All Fields] OR obesitas[All Fields] OR obesitas'[All Fields] OR obesitasban[All Fields] OR obesitasbehandling[All Fields] OR obesitasenheten[All Fields] OR obesitaskirurgi[All Fields] OR obesitaskliniek[All Fields] OR obesitasopererade[All Fields] OR obesitassyndroom[All Fields] OR obesitat[All Fields] OR obesitatii[All Fields] OR obesitax[All Fields] OR obesitax'[All Fields] OR obesite[All Fields] OR obesitehyperglycemie[All Fields] OR obesiteit[All Fields] OR obesites[All Fields] OR obesitet[All Fields] OR obesiti[All Fields] OR obesitic[All Fields] OR obesitics[All Fields] OR obesities[All Fields] OR obesitis[All Fields] OR obesitiy[All Fields] OR obesitogenic[All Fields] OR obesitological[All Fields] OR obesitologists[All Fields] OR obesitology[All Fields] OR obesitv[All Fields] OR obesity[All Fields] OR obesity'[All Fields] OR obesity's[All Fields] OR obesity,[All Fields] OR obesity1[All Fields] OR obesity101[All Fields] OR obesity2[All Fields] OR obesity530[All Fields] OR obesityand[All Fields] OR obesityassociated[All Fields] OR obesityasthma[All Fields] OR obesitydepartment[All Fields] OR obesitydevice[All Fields] OR obesitydiseases[All Fields] OR obesityenhanced[All Fields] OR obesitygene[All Fields] OR obesitygenes[All Fields] OR obesityhealth[All Fields] OR obesityin[All Fields] OR obesityinduced[All Fields] OR obesitylinked[All Fields] OR obesitynational[All Fields] OR obesitynetwork[All Fields] OR obesityprone[All Fields] OR obesityrelated[All Fields] OR obesityresearch[All Fields] OR obesitys[All Fields] OR obesitysurgery[All Fields] OR obesityweek[All Fields] OR obesityyale[All Fields]) AND (rehabilit'aci'o[All Fields] OR rehabilit'aci'oban[All Fields] OR rehabilit'aci'oj'ahoz[All Fields] OR rehabilit'acia[All Fields] OR rehabilit'acii[All Fields] OR rehabilit'aland'ok[All Fields] OR rehabilita[All Fields] OR rehabilita6cna[All Fields] OR rehabilita6cnach[All Fields] OR rehabilita6cni[All Fields] OR rehabilita6cnim[All Fields] OR rehabilitability[All Fields] OR rehabilitable[All Fields] OR rehabilitac'i[All Fields] OR rehabilitacao[All Fields] OR rehabilitace[All Fields] OR rehabilitaci[All Fields] OR rehabilitaci'on[All Fields] OR rehabilitaci6n[All Fields] OR rehabilitacia[All Fields] OR rehabilitacie[All Fields] OR rehabilitacii[All Fields] OR rehabilitaciion[All Fields] OR rehabilitacija[All Fields] OR rehabilitacijah[All Fields] OR rehabilitacijata[All Fields] OR rehabilitacije[All Fields] OR rehabilitaciji[All Fields] OR rehabilitacijo[All Fields] OR rehabilitacijom[All Fields] OR rehabilitacijska[All Fields] OR rehabilitacijski[All Fields] OR rehabilitacijskog[All Fields] OR rehabilitacijskom[All Fields] OR rehabilitacijsku[All Fields] OR rehabilitaciju[All Fields] OR rehabilitacinemocnych[All Fields] OR rehabilitacio[All Fields] OR rehabilitacioban[All Fields] OR rehabilitacioig[All Fields] OR rehabilitacioja[All Fields] OR rehabilitaciojaban[All Fields] OR rehabilitaciojamak[All Fields] OR rehabilitaciojanak[All Fields] OR rehabilitaciojara[All Fields] OR rehabilitaciojarol[All Fields] OR rehabilitaciojat[All Fields] OR rehabilitaciomicronn[All Fields] OR rehabilitacion[All Fields] OR rehabilitaciones[All Fields] OR rehabilitacioni[All Fields] OR rehabilitacionih[All Fields] OR rehabilitacionim[All Fields] OR rehabilitacioniot[All Fields] OR rehabilitacionog[All Fields] OR rehabilitacios[All Fields] OR rehabilitaciou[All Fields] OR rehabilitacioval[All Fields] OR rehabilitaciu[All Fields] OR rehabilitacja[All Fields] OR rehabilitacje[All Fields] OR rehabilitacji[All Fields] OR rehabilitacjti[All Fields] OR rehabilitacju[All Fields] OR rehabilitacloja[All Fields] OR rehabilitacna[All Fields] OR rehabilitacne[All Fields] OR rehabilitacnej[All Fields] OR rehabilitacni[All Fields] OR rehabilitacnich[All Fields] OR rehabilitacniho[All Fields] OR rehabilitacnim[All Fields] OR rehabilitaco[All Fields] OR rehabilitacyjna[All Fields] OR rehabilitacyjne[All Fields] OR rehabilitacyjnego[All Fields] OR rehabilitacyjnej[All Fields] OR rehabilitacyjno[All Fields] OR rehabilitacyjny[All Fields] OR rehabilitacyjnych[All Fields] OR rehabilitacyjnym[All Fields] OR rehabilitado[All Fields] OR rehabilitador[All Fields] OR rehabilitadora[All Fields] OR rehabilitados[All Fields] OR rehabilitain[All Fields] OR rehabilitaion[All Fields] OR rehabilitaition[All Fields] OR rehabilitaitn[All Fields] OR rehabilitaiton[All Fields] OR rehabilitalasa[All Fields] OR rehabilitalasaban[All Fields] OR rehabilitalt[All Fields] OR rehabilitamos[All Fields] OR rehabilitanden[All Fields] OR rehabilitandengruppe[All Fields] OR rehabilitandenzufriedenheit[All Fields] OR rehabilitandinnen[All Fields] OR rehabilitands[All Fields] OR rehabilitant[All Fields] OR rehabilitant's[All Fields] OR rehabilitantow[All Fields] OR rehabilitants[All Fields] OR rehabilitants'[All Fields] OR rehabilitasarol[All Fields] OR rehabilitasie[All Fields] OR rehabilitasiediens[All Fields] OR rehabilitasieprogram[All Fields] OR rehabilitasieprojek[All Fields] OR rehabilitasjon[All Fields] OR rehabilitasyon[All Fields] OR rehabilitasyonda[All Fields] OR rehabilitasyondan[All Fields] OR rehabilitasyonu[All Fields] OR rehabilitasyonunda[All Fields] OR rehabilitat[All Fields] OR rehabilitatable[All Fields] OR rehabilitatacji[All Fields] OR rehabilitatation[All Fields] OR rehabilitatcion[All Fields] OR rehabilitate[All Fields] OR rehabilitate'[All Fields] OR rehabilitated[All Fields] OR rehabilitated'[All Fields] OR rehabilitatedly[All Fields] OR rehabilitates[All Fields] OR rehabilitatie[All Fields] OR rehabilitatie'[All Fields] OR rehabilitatieonderzoek[All Fields] OR rehabilitatiestandpunt[All Fields] OR rehabilitatin[All Fields] OR rehabilitating[All Fields] OR rehabilitatinszentrum[All Fields] OR rehabilitatio[All Fields] OR rehabilitatioja[All Fields] OR rehabilitatiojaban[All Fields] OR rehabilitatiojarol[All Fields] OR rehabilitatiom[All Fields] OR rehabilitation[All Fields] OR rehabilitation'[All Fields] OR rehabilitation"[All Fields] OR rehabilitation's[All Fields] OR rehabilitation,[All Fields] OR rehabilitation1[All Fields] OR rehabilitation4[All Fields] OR rehabilitationa[All Fields] OR rehabilitational[All Fields] OR rehabilitationand[All Fields] OR rehabilitationas[All Fields] OR rehabilitation biochemistrymedical[All Fields] OR rehabilitationcasa[All Fields] OR rehabilitationcase[All Fields] OR rehabilitationcenters[All Fields] OR rehabilitationcentres[All Fields] OR rehabilitationclinical[All Fields] OR rehabilitationdepartment[All Fields] OR rehabilitationdepartments[All Fields] OR rehabilitationdivision[All Fields] OR rehabilitationealing[All Fields] OR rehabilitationen[All Fields] OR rehabilitationfriedrich[All Fields] OR rehabilitationheart[All Fields] OR rehabilitationhospital[All Fields] OR rehabilitationin[All Fields] OR rehabilitationis[All Fields] OR rehabilitationist[All Fields] OR rehabilitationist's[All Fields] OR rehabilitationistanbul[All Fields] OR rehabilitationists[All Fields] OR rehabilitationmedicine[All Fields] OR rehabilitationof[All Fields] OR rehabilitationologists[All Fields] OR rehabilitationplanning[All Fields] OR rehabilitationreconstruction[All Fields] OR rehabilitations[All Fields] OR rehabilitationsabteillung[All Fields] OR rehabilitationsabteilung[All Fields] OR rehabilitationsadaquate[All Fields] OR rehabilitationsambulanz[All Fields] OR rehabilitationsangebot[All Fields] OR rehabilitationsangebotes[All Fields] OR rehabilitationsangleichungsg esetz[All Fields] OR rehabilitationsanliegen[All Fields] OR rehabilitationsanstalt[All Fields] OR rehabilitationsarbeit[All Fields] OR rehabilitationsarztes[All Fields] OR rehabilitationsaufenthaltes[All Fields] OR rehabilitationsaufgabe[All Fields] OR rehabilitationsaufgaben[All Fields] OR rehabilitationsausbildung[All Fields] OR rehabilitationsaussichten[All Fields] OR rehabilitationsbedarf[All Fields] OR rehabilitationsbedarfs[All Fields] OR rehabilitationsbedurftigen[All Fields] OR rehabilitationsbedurftiger[All Fields] OR rehabilitationsbedurftigkeit[All Fields] OR rehabilitationsbegutachtung[All Fields] OR rehabilitationsbehandlung[All Fields] OR rehabilitationsbehandlungen[All Fields] OR rehabilitationsbehand lungsgruppen[All Fields] OR rehabilitationsberater[All Fields] OR rehabilitationsberatung[All Fields] OR rehabilitationsbereich[All Fields] OR rehabilitationsberufe[All Fields] OR rehabilitationsbestimmungen[All Fields] OR rehabilitationsbetrieb[All Fields] OR rehabilitationsbezogene[All 


\section{COPYRIGHT $^{(} 2017$ EDIZIONI MINERVA MEDICA}

APPENDIX I.-The 4 strings used for first selection (continues).

Fields] OR rehabilitationscentrum[All Fields] OR rehabilitationschancen[All Fields] OR rehabilitationschirurgie[All Fields] OR rehabilitationsciences[All Fields] OR rehabilitationsdatenbank[All Fields] OR rehabilitationsdauer[All Fields] OR rehabilitationsdiagnostik[All Fields] OR rehabilitationsdienst[All Fields] OR rehabilitationsdienste[All Fields] OR rehabilitationsdienstleistungen[All Fields] OR rehabilitationseffekte[All Fields] OR rehabilitationseffekten[All Fields] OR rehabilitationseinheit[All Fields] OR rehabilitationseinleitung[All Fields] OR rehabilitationseinrichtung[All Fields] OR rehabilitationseinrichtungen[All Fields] OR rehabilitationserfassung[All Fields] OR rehabilitationserfolg[All Fields] OR rehabilitationserfolges[All Fields] OR rehabilitationserfolgs[All Fields] OR rehabilitationsergebnisse[All Fields] OR rehabilitationsergebnissen[All Fields] OR rehabilitationsergebnisses[All Fields] OR rehabilitationservice[All Fields] OR rehabilitationsexperten[All Fields] OR rehabilitationsfachklinik[All Fields] OR rehabilitationsfahiger[All Fields] OR rehabilitationsfahigkeit[All Fields] OR rehabilitationsfaktor[All Fields] OR rehabilitationsfall[All Fields] OR rehabilitationsfalle[All Fields] OR rehabilitationsforderung[All Fields] OR rehabilitationsformen[All Fields] OR rehabilitationsforschung[All Fields] OR rehabilitationsfortschritts[All Fields] OR rehabilitationsfragebogen[All Fields] OR rehabilitationsfragen[All Fields] OR rehabilitationsfunktion[All Fields] OR rehabilitationsgesetz[All Fields] OR rehabilitationsgrundlinien[All Fields] OR rehabilitationsheilverf ahren[All Fields] OR rehabilitationshiatus[All Fields] OR rehabilitationshilfe[All Fields] OR rehabilitationshilfen[All Fields] OR rehabilitationshinweisen[All Fields] OR rehabilitationskandidaten[All Fields] OR rehabilitationskette[All Fields] OR rehabilitationskilinik[All Fields] OR rehabilitationskinderklinik[All Fields] OR rehabilitationsklinik[All Fields] OR rehabilitationskliniken[All Fields] OR rehabilitationsklinikum[All Fields] OR rehabilitationskommission[All Fields] OR rehabilitationskomplex[All Fields] OR rehabilitationskongress[All Fields] OR rehabilitationskonzept[All Fields] OR rehabilitationskonzepte[All Fields] OR rehabilitationskonzepts[All Fields] OR rehabilitationskrankenhaus[All Fields] OR rehabilitationskrankenhauses[All Fields] OR rehabilitationskur[All Fields] OR rehabilitationskuren[All Fields] OR rehabilitationslehrgangs[All Fields] OR rehabilitationsleistungen[All Fields] OR rehabilitationsmafssnahmen[All Fields] OR rehabilitationsmanagement[All Fields] OR rehabilitationsmasscost[All Fields] OR rehabilitationsmassnahme[All Fields] OR rehabilitationsmassnahmen[All Fields] OR rehabilitationsmedikation[All Fields] OR rehabilitationsmedizin[All Fields] OR rehabilitationsmediziners[All Fields] OR rehabilitationsmedizinische[All Fields] OR rehabilitationsm edizinischer[All Fields] OR rehabilitationsmedzin[All Fields] OR rehabilitationsmethode[All Fields] OR rehabilitationsmodell[All Fields] OR rehabilitationsmodells[All Fields] OR rehabilitationsmoglichkeilen[All Fields] OR rehabilitationsmoglichkeit[All Fields] OR rehabilitationsmoglichkeit en[All Fields] OR rehabilitationsnachsorge[All Fields] OR rehabilitationsnachsorgeprogramm[All Fields] OR rehabilitationsneurologie[All Fields] OR rehabilitationsoperation[All Fields] OR rehabilitationsoptimierung[All Fields] OR rehabilitationsoptionen[All Fields] OR rehabilitationsorientierte[All Fields] OR rehabilitationsorthesen[All Fields] OR rehabilitationspadagogik[All Fields] OR rehabilitationspadagogische[All Fields] OR rehabilitationsp adagogischen[All Fields] OR rehabilitationspadagogischer[All Fields] OR rehabilitationspadagogisches[All Fields] OR rehabilitationspatienten[All Fields] OR rehabilitationspersonal[All Fields] OR rehabilitationspersonals[All Fields] OR rehabilitationspflege[All Fields] OR rehabilitationsphase[All Fields] OR rehabilitationsplan[All Fields] OR rehabilitationsplane[All Fields] OR rehabilitationsplanung[All Fields] OR rehabilitationspolitik[All Fields] OR rehabilitationsport[All Fields] OR rehabilitationspotential[All Fields] OR rehabilitationspraxis[All Fields] OR rehabilitationsprinzips[All Fields] OR rehabilitationsprobleme[All Fields] OR rehabilitationsprognose[All Fields] OR rehabilitationsprogramm[All Fields] OR rehabilitationsprogramme[All Fields] OR rehabilitationsprogrammen[All Fields] OR rehabilitationsprogrammes[All Fields] OR rehabilitationsprogramms[All Fields] OR rehabilitationsprojekt[All Fields] OR rehabilitationsprothesen[All Fields] OR rehabilitationsprotokoll[All Fields] OR rehabilitationsprozess[All Fields] OR rehabilitationsprozesse[All Fields] OR rehabilitationsprozesses[All Fields] OR rehabilitationspsycholgie[All Fields] OR rehabilitationspsychologie[All Fields] OR rehabilitationspsychologischer[All Fields] OR rehabilitationsraum[All Fields] OR rehabilitationsrecht[All Fields] OR rehabilitationsrechtes[All Fields] OR rehabilitationsrechtsverhaltnis[All Fields] OR rehabilitationsrelevanter[All Fields] OR rehabilitationsrichtlinien[All Fields] OR rehabilitatio nssachbearbeitung[All Fields] OR rehabilitationssituation[All Fields] OR rehabilitationsskalen[All Fields] OR rehabilitationssoziologie[All Fields] OR rehabilitationssport[All Fields] OR rehabilitationsstation[All Fields] OR rehabilitationsstationen[All Fields] OR rehabilitationsstrategien[All Fields] OR rehabilitationssystem[All Fields] OR rehabilitationssystems[All Fields] OR rehabilitationsszene[All Fields] OR rehabilitationsteam[All Fields] OR rehabilitationstechnik[All Fields] OR rehabilitationstechnologie[All Fields] OR rehabilitationstherapeut[All Fields] OR rehabilitationstherapie[All Fields] OR rehabilitationstrager[All Fields] OR rehabilitationstraining[All Fields] OR rehabilitationsverbessernde[All Fields] OR rehabilitationsverfahren[All Fields] OR rehabilitationsverfahrens[All Fields] OR rehabilitationsverksamhet[All Fields] OR rehabilitationsverlauf[All Fields] OR rehabilitationsverlaufe[All Fields] OR rehabilitationsverlaufs[All Fields] OR rehabilitationsverzogernde[All Fields] OR rehabilitationsvorbereitung[All Fields] OR rehabilitationsvorbereitungslehrgange[All Fields] OR rehabilitationsvorstellungen[All Fields] OR rehabilitationswerkstatten[All Fields] OR rehabilitationswesen[All Fields] OR rehabilitationswissens[All Fields] OR rehabilitationswissenschaft[All Fields] OR rehabilitationswissenschaften[All Fields] OR rehabilitationswissenschaftler[All Fields] OR rehabilitationswissenschaftliche[All Fields] OR rehabilitationswissenschaftlichen[All Fields] OR rehabilitationswissenschaftlicher[All Fields] OR rehabilitationswissenschaftliches[All Fields] OR rehabilitationszentren[All Fields] OR rehabilitationszentrum[All Fields] OR rehabilitationszentrums[All Fields] OR rehabilitationsziele[All Fields] OR rehabilitationszielen[All Fields] OR rehabilitationszuweisung[All Fields] OR rehabilitationtherapy[All Fields] OR rehabilitationund[All Fields] OR reh abilitationuntersuchungsdesign[All Fields] OR rehabilitationwien[All Fields] OR rehabilitationzentrum[All Fields] OR rehabilitatiton[All Fields] OR rehabilitativ[All Fields] OR rehabilitativa[All Fields] OR rehabilitativas[All Fields] OR rehabilitative[All Fields] OR rehabilitative'[All Fields] OR rehabilitatively[All Fields] OR rehabilitativen[All Fields] OR rehabilitativer[All Fields] OR rehabilitatives[All Fields] OR rehabilitaton[All Fields] OR rehabilitator[All Fields] OR rehabilitator's[All Fields] OR rehabilitatoria[All Fields] OR rehabilitatorio[All Fields] OR rehabilitators[All Fields] OR rehabilitators'[All Fields] OR rehabilitatory[All Fields] OR rehabilitatsbestimmung[All Fields] OR rehabilitatsii[All Fields] OR rehabilitatsiia[All Fields] OR rehabilitazione[All Fields] OR rehabilitazji[All Fields] OR rehabilitcaji[All Fields] OR rehabilitcea[All Fields] OR rehabilite[All Fields] OR rehabilited[All Fields] OR rehabilitee[All Fields] OR rehabilitee's[All Fields] OR rehabilitees[All Fields] OR rehabilitees'[All Fields] OR rehabiliter[All Fields] OR rehabilitera[All Fields] OR rehabiliterade[All Fields] OR rehabiliterande[All Fields] OR rehabiliterar[All Fields] OR rehabiliteras[All Fields] OR rehabiliterende[All Fields] OR rehabilitering[All Fields] OR rehabiliteringen[All Fields] OR rehabiliteringens[All Fields] OR rehabiliterings[All Fields] OR rehabiliteringsafdeling[All Fields] OR rehabiliteringsansvar[All Fields] OR rehabiliteringsarbetet[All Fields] OR rehabiliteringsaspkter[All Fields] OR rehabiliteringsavdelingen[All Fields] OR rehabiliteringsavdelning[All Fields] OR rehabiliteringsavdelningar[All Fields] OR rehabiliteringsbehov[All Fields] OR rehabiliteringsbehovet[All Fields] OR rehabiliteringsbehovetar[All Fields] OR rehabiliteringsbidrag[All Fields] OR 


\section{COPYRIGHT ${ }^{\circ} 2017$ EDIZIONI MINERVA MEDICA}

APPENDIX I.-The 4 strings used for first selection (continues).

rehabiliteringsbroms[All Fields] OR rehabiliteringscenter[All Fields] OR rehabiliteringscentrum[All Fields] OR rehabiliteringsenhet[All Fields] OR rehabiliteringsenheten[All Fields] OR rehabiliteringsevnen[All Fields] OR rehabiliteringsforlob[All Fields] OR rehabiliteringsforlop[All Fields] OR rehabiliteringsforsok[All Fields] OR rehabiliteringsfragan[All Fields] OR rehabiliteringsfragor[All Fields] OR rehabiliteringsgarantin[All Fields] OR rehabiliteringsinsatser[All Fields] OR rehabiliteringsinsatserna[All Fields] OR rehabiliteringsinstrument[All Fields] OR rehabiliteringskedjan[All Fields] OR rehabiliteringsklinik[All Fields] OR rehabiliteringskliniken[All Fields] OR rehabiliteringskurs[All Fields] OR rehabiliteringslakare[All Fields] OR rehabiliteringsmedicin[All Fields] OR rehabiliteringsmedicinare[All Fields] OR rehabiliteringsmedicinska[All Fields] OR rehabiliteringsmedicinskt[All Fields] OR rehabiliteringsmedverkan[All Fields] OR rehabiliteringsmessig[All Fields] OR rehabiliteringsmessige[All Fields] OR rehabiliteringsmetod[All Fields] OR rehabiliteringsomradet[All Fields] OR rehabiliteringsopphold[All Fields] OR rehabiliteringspasienter[All Fields] OR rehabiliteringspenger[All Fields] OR rehabiliteringspersonal[All Fields] OR rehabiliteringspionjar[All Fields] OR rehabiliteringsplasser[All Fields] OR rehabiliteringspotentiale[All Fields]OR rehabiliteringsproblem[AllFields]OR rehabiliteringsproblemet[AllFields]ORrehabiliteringsprognos[AllFields]OR rehabiliteringsprogram[All Fields] OR rehabiliteringsprogrammet[All Fields] OR rehabiliteringspsykiatrin[All Fields] OR rehabiliteringsrad[All Fields] OR rehabiliteringsradet[All Fields] OR rehabiliteringsresultat[All Fields] OR rehabiliteringsresurser[All Fields] OR rehabiliteringssenter[All Fields] OR rehabiliteringssenteret[All Fields] OR rehabiliteringssykehus[All Fields] OR rehabiliteringssystem[All Fields] OR rehabiliteringsteknik[All Fields] OR rehabiliteringstilbud[All Fields] OR rehabiliteringstraning[All Fields] OR rehabiliteringsverksamhet[All Fields] OR rehabiliteringsverksamheten[All Fields] OR rehabilites[All Fields] OR rehabilitiation[All Fields] OR rehabilitiative[All Fields] OR rehabilitier[All Fields] OR rehabilitierbaren[All Fields] OR rehabilitieren[All Fields] OR rehabilitierende[All Fields] OR rehabilitierenden[All Fields] OR rehabilitiert[All Fields] OR rehabilitierte[All Fields] OR rehabilitierten[All Fields] OR rehabilitierter[All Fields] OR rehabilitierung[All Fields] OR rehabilities[All Fields] OR rehabiliting[All Fields] OR rehabilition[All Fields] OR rehabilititation[All Fields] OR rehabilititave[All Fields] OR rehabilitive[All Fields] OR rehabilitiven[All Fields] OR rehabilitize[All Fields] OR rehabilitologist[All Fields] OR rehabilitology[All Fields] OR rehabilitons[All Fields] OR rehabilitory[All Fields] OR rehabilitovanych[All Fields] OR rehabilitowac[All Fields] OR rehabilitowanych[All Fields] OR rehabilitracji[All Fields] OR rehabilitranim[All Fields] OR rehabilitration[All Fields] OR rehabilittion[All Fields] OR rehabilitujacych[All Fields] OR rehabilituju[All Fields] OR rehability[All Fields] OR rehabilityoregon[All Fields] OR rehabilitzation[All Fields]) AND (diabete[All Fields] OR diabete's[All Fields] OR diabetec[All Fields] OR diabetecheskoi[All Fields] OR diabeted[All Fields] OR diabetees[All Fields] OR diabeteic[All Fields] OR diabeteics[All Fields] OR diabetekere[All Fields] OR diabetekseen[All Fields] OR diabetekselta[All Fields] OR diabeteksen[All Fields] OR diabeteksessa[All Fields] OR diabetelogical[All Fields] OR diabetelogie[All Fields] OR diabetelogy[All Fields] OR diabetelugano[All Fields] OR diabetem[All Fields] OR diabeten[All Fields] OR diabetenkosten[All Fields] OR diabeteology[All Fields] OR diabeteom[All Fields] OR diabeter[All Fields] OR diabeterelated[All Fields] OR diabetergestemd[All Fields] OR diabeterisiko[All Fields] OR diabeters[All Fields] OR diabetes[All Fields] OR diabetes'[All Fields] OR diabetes"[All Fields] OR diabetes'risk[All Fields] OR diabetes's[All Fields] OR diabetes,[All Fields] OR diabetes1[All Fields] OR diabetes3[All Fields] OR diabetes39[All Fields] OR diabetes64[All Fields] OR diabetes96[All Fields] OR diabetesa[All Fields] OR diabetesabteilung[All Fields] OR diabetesacidos[All Fields] OR diabetesadelaide[All Fields] OR diabetesahnliche[All Fields] OR diabetesaktion[All Fields] OR diabetesalfred[All Fields] OR diabetesambulanz[All Fields] OR diabetesambulanzen[All Fields] OR diabetesambulatorier[All Fields] OR diabetesambulatoriet[All Fields] OR diabetesambulatorium[All Fields] OR diabetesamerica[All Fields] OR diabetesand[All Fields] OR diabetesandendocrinology[All Fields] OR diabetesanyagcserere[All Fields] OR diabetesassistentin[All Fields] OR diabetesassociated[All Fields] OR diabetesatlas[All Fields] OR diabetesauslosung[All Fields] OR diabetesaustin[All Fields] OR diabetesaustralia[All Fields] OR diabetesbarn[All Fields] OR diabetesbarnmorska[All Fields] OR diabetesbb[All Fields] OR diabetesbehandeling[All Fields] OR diabetesbehandling[All Fields] OR diabetesbehandlingen[All Fields] OR diabetesbehandlugn[All Fields] OR diabetesbehandlung[All Fields] OR diabetesbekampfung[All Fields] OR diabetesben[All Fields] OR diabetesberater[All Fields] OR diabetesberaterin[All Fields] OR diabetesberatung[All Fields] OR diabetesbetreuung[All Fields] OR diabetesbewaltigung[All Fields] OR diabetesbezogene[All Fields] OR diabetesbirmingham[All Fields] OR diabetesblizard[All Fields] OR diabetesborn[All Fields] OR diabetescare[All Fields] OR diabetescarecenter[All Fields] OR diabetescareprogram[All Fields] OR diabetescenter[All Fields] OR diabetescentrum[All Fields] OR diabetescoach[All Fields] OR diabetescontrol[All Fields] OR diabetescontrole[All Fields] OR diabetescontroles[All Fields] OR diabetesdagen[All Fields] OR diabetesdagvard[All Fields] OR diabetesdauer[All Fields] OR diabetesde[All Fields] OR diabetesdebut[All Fields] OR diabetesdefinition[All Fields] OR diabetesdepartment[All Fields] OR diabetesdiaet[All Fields] OR diabetesdiagnose[All Fields] OR diabetesdiagnosen[All Fields] OR diabetesdiagnostik[All Fields] OR diabetesdiat[All Fields] OR diabetesdieet[All Fields] OR diabetesdigestivekidney[All Fields] OR diabetesdisc[All Fields] OR diabetesdispensar[All Fields] OR diabetesdivision[All Fields] OR diabetesdue[All Fields] OR diabetese[All Fields] OR diabeteseducatie[All Fields] OR diabeteseinstellung[All Fields] OR diabeteselisenstrasse[All Fields] OR diabetesendocrinology[All Fields] OR diabetesenheten[All Fields] OR diabetesentwicklung[All Fields] OR diabetesepidemien[All Fields] OR diabeteserhebung[All Fields] OR diabeteserkrankung[All Fields] OR diabeteserkrankungen[All Fields] OR diabeteses[All Fields] OR diabetesesben[All Fields] OR diabetesesek[All Fields] OR diabetesesekben[All Fields] OR diabeteseseken[All Fields] OR diabetesexercise[All Fields] OR diabetesexercised[All Fields] OR diabetesfalle[All Fields] OR diabetesfalles[All Fields] OR diabetesfederatie[All Fields] OR diabetesfiona[All Fields] OR diabetesflut[All Fields] OR diabetesforbund[All Fields] OR diabetesforbundet[All Fields] OR diabetesforekomst[All Fields] OR diabetesforeningen[All Fields] OR diabetesform[All Fields] OR diabetesformakban[All Fields] OR diabetesformen[All Fields] OR diabetesforms[All Fields] OR diabetesforschg[All Fields] OR diabetesforschung[All Fields] OR diabetesforschungsinsititutes[All Fields] OR diabetesforschungsinstitut[All Fields] OR diabetesforschungsinstitutes[All Fields] OR diabetesforschungsinstituts[All Fields] OR diabetesforskning[All Fields] OR diabetesforskningscentret[All Fields] OR diabetesforskningssenter[All Fields] OR diabetesforskningssenteret[All Fields] OR diabetesfrage[All Fields] OR diabetesfragen[All Fields] OR diabetesfrail[All Fields] OR diabetesfruhdiagnostik[All Fields] OR diabetesfruherkennung[All Fields] OR diabetesfruhstadien[All Fields] OR diabetesfuhrung[All Fields] OR diabetesfursorge[All Fields] OR diabetesgangran[All Fields] OR diabetesgeeni[All Fields] OR diabetesgefahrdeten[All Fields] OR diabetesgenes[All Fields] OR diabetesgenetikk[All Fields] OR diabetesgesellschaft[All Fields] OR diabetesgondozasban[All Fields] OR diabetesgondozo[All Fields] OR diabetesgravida[All Fields] OR diabetesgraviditet[All Fields] OR diabetesgruppen[All Fields] OR diabeteshaufigkeit[All Fields] OR diabetesheilung[All Fields] OR diabeteshellenic[All Fields] OR diabeteshereditat[All Fields] OR diabeteshistorie[All Fields] OR diabeteshoitajakoulutusta[All Fields] OR diabeteshulpmiddelen[All Fields] OR diabetesin[All Fields] OR diabetesincidensregister[All Fields] OR diabetesincidensstudien[All Fields] OR diabetesincontrol[All Fields] OR diabetesindia[All Fields] OR 


\section{COPYRIGHT ${ }^{\circledR} 2017$ EDIZIONI MINERVA MEDICA}

APPENDIX I.-The 4 strings used for first selection (continues).

diabetesinduced[All Fields] OR diabetesinflammation[All Fields] OR diabetesinstitut[All Fields] OR diabetesinstitute[All Fields] OR diabetesinstruktion[All Fields] OR diabetesinsulin[All Fields] OR diabetesinterventions[All Fields] OR diabetesinterventionsstudie[All Fields] OR diabetesinzidenz[All Fields] OR diabetesinzidenzstudiengruppe[All Fields] OR diabetesis[AllFields] OR diabetesjapan[All Fields] OR diabeteskatarakt[All Fields] OR diabetesklinik[All Fields] OR diabetesklinikka[All Fields] OR diabeteskockazat[All Fields] OR diabeteskoloni[All Fields] OR diabeteskoma[All Fields] OR diabeteskomplikasjoner[All Fields] OR diabeteskomplikation[All Fields] OR diabeteskomplikationen[All Fields] OR diabeteskomplikationer[All Fields] OR diabeteskongress[All Fields] OR diabeteskontroll[All Fields] OR diabeteskontrolle[All Fields] OR diabeteskontrollen[All Fields] OR diabeteskost[All Fields] OR diabeteskosthold[All Fields] OR diabeteskranke[All Fields] OR diabeteskranken[All Fields] OR diabeteskurssi[All Fields] OR diabetesl[All Fields] OR diabeteslaake[All Fields] OR diabeteslaakkeen[All Fields] OR diabeteslaakkeet[All Fields] OR diabeteslaakkeiden[All Fields] OR diabeteslaboratoriet[All Fields] OR diabeteslakemedel[All Fields] OR diabetesliiton[All Fields] OR diabeteslijders[All Fields] OR diabeteslike[All Fields] OR diabeteslive[All Fields] OR diabetesludwig[All Fields] OR diabetesmanagement[All Fields] OR diabetesmanifestation[All Fields] OR diabetesmaske[All Fields] OR diabetesmedel[All Fields] OR diabetesmediciner[All Fields] OR diabetesmedikamente[All Fields] OR diabetesmeds[All Fields] OR diabetesmellitus[All Fields] OR diabetesmetabolic[All Fields] OR diabetesmetabolism[All Fields] OR diabetesmidler[All Fields] OR diabetesmikroangiopati[All Fields] OR diabetesmine[All Fields] OR diabetesmittel[All Fields] OR diabetesmittels[All Fields] OR diabetesmodell[All Fields] OR diabetesmodrar[All Fields] OR diabetesmolecular[All Fields] OR diabetesmorbidit[All Fields] OR diabetesmorbiditat[All Fields] OR diabetesmorbiditet[All Fields] OR diabetesmortalitat[All Fields] OR diabetesmottagning[All Fields] OR diabetesmottagningen[All Fields] OR diabetesnational[All Fields] OR diabetesnd[All Fields] OR diabetesne[All Fields] OR diabetesnefropati[All Fields] OR diabetesnet[All Fields] OR diabetesneuropathien[All Fields] OR diabetesneuropati[All Fields] OR diabetesnewfrontiers[All Fields] OR diabetesnotfalle[All Fields] OR diabetesnp[All Fields] OR diabetesnsw[All Fields] OR diabetesobesity[All Fields] OR diabetesom[All Fields] OR diabetesomsorg[All Fields] OR diabetesomsorgen[All Fields] OR diabetesoutcomequality[All Fields] OR diabetespasienter[All Fields] OR diabetespathogenese[All Fields] OR diabetespathogenesen[All Fields] OR diabetespatient[All Fields] OR diabetespatienten[All Fields] OR diabetespatienter[All Fields] OR diabetespatienters[All Fields] OR diabetespatogenesen[All Fields] OR diabetespflege[All Fields] OR diabetesplan[All Fields] OR diabetespoliklinikka[All Fields] OR diabetespoliklinikken[All Fields] OR diabetespolyneuropathie[All Fields] OR diabetespopulation[All Fields] OR diabetespotilaan[All Fields] OR diabetespraevalens[All Fields] OR diabetespravalenz[AllFields] OR diabetespravention[All Fields]OR diabetesprincess[AllFields] OR diabetesproblem[All Fields] OR diabetesprobleme[All Fields] OR diabetesproblemen[All Fields] OR diabetesproduced[All Fields] OR diabetesprone[All Fields] OR diabetespsychosen[All Fields] OR diabetespubs[All Fields] OR diabetesrask[All Fields] OR diabetesregister[All Fields] OR diabetesregisters[All Fields] OR diabetesregistret[All Fields] OR diabetesregulatie[All Fields] OR diabetesregulation[All Fields] OR diabetesregulationen[All Fields] OR diabetesregulering[All Fields] OR diabetesrekommendationer[All Fields] OR diabetesrelated[All Fields] OR diabetesrelaterade[All Fields] OR diabetesremission[All Fields] OR diabetesremissionen[All Fields] OR diabetesresearch[All Fields] OR diabetesretinopati[All Fields] OR diabetesrisiko[All Fields] OR diabetesrol[All Fields] OR diabetessar[All Fields] OR diabetesscenariosforjuniordoctors[All Fields] OR diabetesschilderung[All Fields] OR diabetesschulung[All Fields] OR diabetesschulungen[All Fields] OR diabetesschwerpunkpraxis[All Fields] OR diabetesschwerpunktpraxis[All Fields] OR diabetesschwestern[All Fields] OR diabetesscreening[All Fields] OR diabetesseinstellung[All Fields] OR diabetesshanghai[All Fields] OR diabetessimuleringsmodel[All Fields] OR diabetessituation[All Fields] OR diabetessjuka[All Fields] OR diabetessjukdomen[All Fields] OR diabetessjukdomens[All Fields] OR diabetessjukvard[All Fields] OR diabetesskola[All Fields] OR diabetesskole[All Fields] OR diabetesskolen[All Fields] OR diabetesskoterskan[All Fields] OR diabetesskoterskornas[All Fields] OR diabetessoftware[All Fields] OR diabetesspecific[All Fields] OR diabetesspecifikus[All Fields] OR diabetesspezifische[All Fields] OR diabetesst[All Fields] OR diabetesstadien[All Fields] OR diabetesstation[All Fields] OR diabetesstiftelsen[All Fields] OR diabetesstudie[All Fields] OR diabetesstudien[All Fields] OR diabetesstudy[All Fields] OR diabetesstuttgart[All Fields] OR diabetessuchaktionen[All Fields] OR diabetessuche[All Fields] OR diabetessuchprogramms[All Fields] OR diabetessurgeryinstitute[All Fields] OR diabetessuspekten[All Fields] OR diabetessystematic[All Fields] OR diabetesszel[All Fields] OR diabetesszures[All Fields] OR diabetesta[All Fields] OR diabetestalk[All Fields] OR diabetestechnologie[All Fields] OR diabetestechnology[All Fields] OR diabetesterapi[All Fields] OR diabetesterapis[All Fields] OR diabetesthe[All Fields] OR diabetestherapei[All Fields] OR diabetestherapie[All Fields] OR diabetestilfaelde[All Fields] OR diabetestipo[All Fields] OR diabetestodes[All Fields] OR diabetestrial[All Fields] OR diabetestuberkulose[All Fields] OR diabetestutkimuksen[All Fields] OR diabetestyp[All Fields] OR diabetestypen[All Fields] OR diabetestypische[All Fields] OR diabetestypischer[All Fields] OR diabetestyps[All Fields] OR diabetesuberwachung[All Fields] OR diabetesundersogelse[All Fields] OR diabetesungdomars[All Fields] OR diabetesuniversity[All Fields] OR diabetesursache[All Fields] OR diabetesursachen[All Fields] OR diabetesvandrejournal[All Fields] OR diabetesvard[All Fields] OR diabetesvarden[All Fields] OR diabetesverdachtigen[All Fields] OR diabetesvereniging[All Fields] OR diabetesverlauf[All Fields] OR diabetesvloedgolf[All Fields] OR diabetesvorkommen[All Fields] OR diabetesvorstadien[All Fields] OR diabetesweekly[All Fields] OR diabeteswelle[All Fields] OR diabetesxglucose[All Fields] OR diabetesz[All Fields] OR diabeteszambulancia[All Fields] OR diabeteszben[All Fields] OR diabeteszentrum[All Fields] OR diabeteszentrums[All Fields] OR diabeteszes[All Fields] OR diabeteszorg[All Fields] OR diabeteszt[All Fields] OR diabetetes[All Fields] OR diabetetogenesis[All Fields] OR diabetetogenic[All Fields] OR diabetets[All Fields] OR diabetetszentrum[All Fields] OR diabeteund[All Fields] OR diabetex[All Fields] OR diabetezentrum[All Fields]) AND Clinical Trial[ptyp]

String 2) PUBMED: obesit* AND rehabilit*AND ( ( Guideline[ptyp] OR Meta-Analysis[ptyp] OR Randomized Controlled Trial[ptyp] OR systematic[sb] ) )

String 3) PUBMED: “Obesity/rehabilitation”[Mesh] AND (Guideline[ptyp] OR Meta-Analysis[ptyp] OR Randomized Controlled Trial[ptyp] OR Review[ptyp] OR systematic[sb])

String 4) COCHRANE: http://onlinelibrary.wiley.com/cochranelibrary/search/mesh?searchRow.searchCriteria.meshTerm $=\% 22 \mathrm{Obesity} \% 22$ \&searchRow.searchOptions.qualifiers $=$ Q000534\&searchMesh=Lookup\&searchRow.ordinal=0\&hiddenFields.strategySortBy $=1$ last-modified$\underline{\text { date } \% 3 B d e s c \& h i d d e n F i e l d s . s h o w S t r a t e g i e s=f a l s e \& h i d d e n F i e l d s . c o n t a i n e r I d=\& h i d d e n F i e l d s . e t a g=\& h i d d e n F i e l d s . o r i g i n a l C o n t a i n e r I d ~}$ 


\section{COPYRIGHT $^{(} 2017$ EDIZIONI MINERVA MEDICA}

APPENDIX II.-Papers retrieved from the search.

1. Pownall HJ, Bray GA, Wageknecht LE, Walkup MP, Heshka S, Hubbard VS, et al. Look AHEAD Research Group. Changes in body composition ober 8 years in a randomized trial of a lifestyle intervention: the look AHEAD study. Obesity 2015;23:565-72.

2. Houston DK, Leng X, Bray GA, Hergenroeder AL, Hill JO, Jakicic $\mathrm{JM}$, et al. Action for Health in Diabetes [Look AHEAD] Movement and Memory Ancillary Study Research Group. Obesity 2015;23:7784.

3. Coen PM, Tanner CJ, Helbling NL, Dubis GS, Hames KC, Xie H, et al. Clinical trial demonstrates exercise following bariatric surgery improves insulin sensitivity. J Clin Invest 2015;125:248-57.

4. Yamada T, Hara K, Svensson AK, Shojima N, Hosoe J, Iwasaki M, et al. Successfully achieving target weight loss influences subsequent maintenance o flower weight and dropout from treatment. Obesity 2015;23:183-91.

5. Khoja SS, Susko AM, Josbeno DA, Piva SR, Fitzgerald GK. Comparing physical activity programs for managing ostheoarthritis in overweight or obese patients. J Comp Eff Res 2014;3:283-99.

6. Unick JL, Beavers D, Bond DS, Clark JM, Jakicic JM, Kitabchi AE, et al. Look AHEAD Research Group. Am J Med 2013;126:236-42.

7. Goodpaster BH, Delany JP, Otto AD, Kuller L, Vockley J, South-Paul $\mathrm{JE}$, et al. Effects of diet and physical activity interventions on weight loss and cardiometabolic risk factors in severely obese adults: a randomized trial. JAMA 2010;304:1795-802.

8. Look AHEAD Research Group, Wing RR. Long term effects of a lifestyle intervention on weight and cardiovascular risk factors in individuals with type 2 diabetes mellitus: four year results o fthe Look AHEAD trial. Ann Intern Med 2010;170:1566-75.

9. Wiltink J, Dippel A, Szczepanski M, Thiede R, Alt C, Beutel ME. Long-term weight loss maintenance after inpatient psychotherapy of severely obese patients based on a randomized study: predictors and maintaining factors of health behavior. J Psychosom Res 2007;62:691-8.

10. Labrune'e et al. Annals of Physical and Rehabilitation Medicine 2012;55:415-29

11. Ma J, Strub P, Xiao L, Lavori PW, Camargo CA Jr, Wilson SR, et al. behavioral weight loss and physical activity intervention in obese adults with asthma: a randomized trial. Ann Am Thorac Soc $2015 ; 12: 1-11$.

12. Teixeira PJ, Carraça EV, Marques MM, Rutter H, Oppert JM, De Bourdeaudhuij I, et al. Successful behavior change in obesity interventions in adults: a systematic review of self-regulation mediators. BMC Medicine 2015;13:84.

13. Maciejewski ML, Patrick DL, Williamson DF. A structured review of randomized controlled trials of weight loss showed little improvement in health-related quality of life. J Clin Epidemiol 2005;58:56878.

14. Vinkers CD, Adriaanse MA, Kroese FM, de Ridder DT. Efficacy of a self-management intervention for weight control in overweight and obese adults: a randomized controlled trial. J Behav Med 2014;37:781-92

15. Sukala WR, Page R, Lonsdale C, Lys I, Rowlands D, Krebs J, et al. Exercise improves quality of life in indigenous Polynesian peoples with type 2 diabetes and visceral obesity. J Phys Act Health 2013:10:699-707.

16. Yank V, Stafford RS, Rosas LG, Ma J. Basline reach and adoption characteristics in a randomized controlled trial of two weight loss interventions translated into primary care: a structured report of realworld applicability. Contemp Clin Trials 2013;34:126-35.

17. Wang CJ, fetzer SJ, Yang YC, Wang WL. The efficacy of using selfmonitoring diaries in a weight loss program for chronically ill obese adults in a rural area. J Nurs Res 2012;20:181-8.

18. Foster GD, Wyatt HR, Hill JO, Makris AP, Rosenbaum DL, Brill $\mathrm{C}$, et al. Weight and metabolic outcomes after 2 years on a low-carbohydrate versus low-fat diet: a randomized trial. Ann Intern Med 2010;153:147-57.

19. Van Sluijs EM, van Poppel MN, Twisk JW, Chin A, Paw MJ, Calfas $\mathrm{KJ}$, et al. Effect of a tailored physical activity intervention delivered in general practice settings: results of a randomized controlled trial. Am J Public Health 2005;95:1825-31.

20. Mayer-Davis EJ, D'Antonio AM, Smith SM, Kirkner G, Levin Martin S, Parra-Medina D, et al. Pounds off with empowerment (POWER):a clinical trial of weight management strategies for black and white adults with diabetes who live in medically underserved rural communities. Am J Public Health 2004;94:1736-42.

21. Wolf AM, Conway MR, Crowther JQ, Hazen KY, Nadler J, Oneida $\mathrm{B}$, et al. Improving control with activity and nutrition [ICAN] study. Translating lifestyle intervention to practice in obese patients with type 2 diabetes. Diabetes Care 2004;27:1570-6.

22. (European Clinical Guide Line) Scottish Intercollegiate Guidelines Network (SIGN). Management of Obesity. A national clinical guideline. Published: February 2010

23. (European Clinical Guide Line) Hauner H, Buchholz G, Hamann A, Husemann B, Koletzko B, Liebermeister H, et al. Prevention and Treatment of Obesity. Published: May 2007.

24. (European Clinical Guide Line) NICE. Obesity: identifification, assessment and management. Clinical guideline Published: 27 November 2014.

25. (European Clinical Guide Line) Yumuk V, Tsigos C, Fried M, Schindler K, Busetto L, Micic D, Toplak H for the Obesity Management Task Force of the European Association for the Study of Obesity. European Guidelines for Obesity Management in Adults. Obes Facts 2015;8:402-24.

26. (European Clinical Guide Line) Standard Italiani per la Cura dell'Obesità S.I.O./A.D.I. 2012/2013.

27. (American Clinical Guide Line) Jensen MD, Ryan DH, Apovian CM, Loria CM, Ard JD, Millen BE, et al. 2013 AHA/ACC/TOS Guideline for the Management of Overweight and Obesity in Adults: A Report of the American College of Cardiology/American Heart Association Task Force on Practice Guidelines and The Obesity Society. J Am Coll Cardiol 2013

28. Brosseau L, Wells GA, Tugwell P, Egan M, Dubouloz CJ, Casimiro L, et al. Ottawa Panel Evidence-Based Clinical Practice Guidelines for the Management of Osteoarthritis in Adults Who Are Obese or Overweight. Phys Ther 2011;91:843-61.

29. (Expert) Capodaglio P, Donini LM, Petroni ML, Brunani A, Dalle Grave R, Di Flaviano CE, et al. Rehabilitation in Obesity with comorbidities. A consensus document from experts of the Italian Society of Physical and Rehabilitation Medicine (SIMFER), the Italian Society of Obesity (SIO) and the Italian Society of Eating Disorders (SISDCA). Eat Weight Disord 2014;19:383-6.

30. (Expert) Obesity Expert Panel of the American College of Cardiology/American Heart Association Task Force on Practice Guidelines and The Obesity Society. 